A. S. Barnay · C. Ellien · F. Gentil · E. Thiébaut

\title{
A model study on variations in larval supply: are populations of the polychaete Owenia fusiformis in the English Channel open or closed?
}

Received: 13 February 2002 / Accepted: 12 July 2002 / Published online: 21 November 2002

(C) Springer-Verlag and AWI 2002

\begin{abstract}
The polychaete Owenia fusiformis is one of the most ecologically important species in the muddy fine sand sediments in the English Channel where it is distributed in geographically separated populations. A vertically averaged Lagrangian hydrodynamic model integrating tidal residual currents and wind-induced currents was used to drive an advection-diffusion model for investigating the variability of larval transport in order to assess the self-seeding capabilities and the degree of connectivity between local populations. Three different types of environmental forcing (i.e. tidal forcing alone, tidal forcing coupled with either NE winds or SW winds) were applied to 19 distinct populations. Without wind influence, self-seeding is the principal mechanism involved in the renewal of most populations. However, larval retention ranged from under $1 \%$ up to $81 \%$ in relation to the adult habitat size and the mean velocity of tidal residual currents. Wind forcing had a strong influence on larval dispersal patterns by modifying the origin and densities of settlers as well as the degree of connectivity between populations. As a consequence, larval supply from distant populations generally exceeded local supply and the inter-annual variability of wind forcing induced large year-to-year variations in larval settlement rates. Larval exchanges occurred mainly between
\end{abstract}

Communicated by W. Armonies, M. Strasser and K. Reise

A.S. Barnay $\cdot$ C. Ellien $\cdot$ E. Thiébaut $(\square)$

Université Pierre et Marie Curie - Paris VI,

Laboratoire d'Océanologie Biologique, CNRS UMR 7093,

Bâtiment A, Case 6, 4 Place Jussieu, 75252 Paris cedex 05,

France

e-mail: eric.thiebaut@snv.jussieu.fr

Tel.: +33-1-44273149, Fax: +33-1-44275250

F. Gentil

Observatoire Océanologique de Roscoff,

Université Pierre et Marie Curie - Paris VI, CNRS UMR 7127,

Place Georges Teissier, BP 74, 29682 Roscoff cedex, France

Present address:

C. Ellien, Department of Oceanography and Fisheries,

University of the Azores, 9901-862 Horta, Azores, Portugal neighbouring populations and three groups of interconnected local populations were thereby identified. Within each group, settlement patterns were related to inter-annual variations in the direction and magnitude of larval exchanges.

Keywords Larval dispersal · Recruitment - Open populations $\cdot$ Modelling $\cdot$ Owenia fusiformis

\section{Introduction}

In coastal zones, most marine benthic invertebrates possess a planktonic larval stage, thereby promoting physical transport of larvae over periods ranging from days to weeks (Eckman 1996). Larvae may be dispersed considerable distances away from their spawning locations with little likelihood of return to the parental population. Such transport is either advantageous if it ensures the maintenance of gene flow among spatially isolated populations and a rapid recolonisation of habitats after a local extinction, or disadvantageous if the larvae settle on unsuitable substrates. Conversely, local hydrodynamics and biological features may restrict larval dispersal close to their source populations. Thus, according to adult distribution patterns and the scales of larval dispersal, marine populations can be demographically defined as either closed or open (Caley et al. 1996). A closed population is only regulated by the local production of offspring that settle in the parental population. However, because of long-distance larval dispersal, the majority of marine populations are open, so that recruitment is uncoupled from local reproduction (Caley et al. 1996). Local populations are therefore maintained by allochthonous larval supply, which may be of mixed origin (Botsford et al. 1994). Because larval supply is a key parameter in the dynamics of adult populations and ultimately in the structure of marine benthic communities (Roughgarden et al. 1988; Underwood and Fairweather 1989), a sufficient knowledge of its variability in time and space is necessary to better understand the fluctuations of adult 
abundance and properly manage coastal resources and habitats (Botsford et al. 1998).

In the English Channel, strong spatial gradients of tidal current velocities control the distribution of superficial sediments and benthic communities (Cabioch et al. 1977; Larsonneur et al. 1982). While pebble and gravel communities dominate the open sea, muddy fine sands are confined to bays and estuaries. Consequently, the tubebuilding polychaete, Owenia fusiformis, which is an ecologically important species of the fine sediments (Dauvin and Gillet 1991; Thiébaut et al. 1997), is mainly distributed in spatially isolated local populations. $O$. fusiformis is a gonochoric species with an adult life span of about 3-4 years (Ménard et al. 1989), a time-limited spawning period in spring (i.e. May-June) (Gentil et al. 1990), and a larval duration of about one month (Wilson 1932; Thiébaut et al. 1992). Previous field studies on O. fusiformis larval distribution only focused at a local level within the Bay of Seine (Thiébaut et al. 1992, 1994). However, they highlighted the respective roles of tidal residual currents and wind-induced currents on larval dispersal, and suggested that larval retention could favour local recruitment despite significant transport of larvae out of the bay. Nevertheless, larval exchanges between neighbouring populations at a larger spatial scale were not well understood due to difficulties in tracking larvae and determining their trajectories and origins (Thiébaut et al. 1994).

At large spatial scales, the use of a modelling approach is more appropriate than field studies in investigating larval dispersal patterns and exchanges for a large range of hydrodynamic conditions (Tremblay et al. 1994; Ellien et al. 2000; Incze and Naimie 2000). Long-term currents in coastal zones are generally driven by tides, wind and density gradients, with the two former mechanisms playing a major role in the English Channel (Salomon 1990, 1991). Density gradients due to temperature and/or salinity differences are weak because of intense tidal mixing, moderate insolation and the lack of high freshwater discharge, except locally near the Seine estuary (Salomon 1990). Their influences on flow fields are restricted to the western Channel entrance in summer and to the eastern part of the Bay of Seine (Salomon 1991). Thus, considering the general hydrodynamic conditions in the Channel, the use of a two-dimensional vertically averaged hydrodynamic model can be acceptable in a first approximation for most of the study area to simulate larval dispersal (Ellien 2001). Using such a model, the objectives of the present study on Owenia fusiformis are (1) to determine the variability of larval dispersal in relation to the spatial and temporal variability of the hydrodynamic environment at the scale of a basin, and (2) to assess the self-seeding capabilities and the degree of connectivity between populations.

\section{Materials and methods}

\section{Numerical model}

The numerical model used in the present study is a 2-D hydrodynamic Lagrangian model, the limits of which are $48^{\circ} 18^{\prime} \mathrm{N}$ and $51^{\circ} 20^{\prime} \mathrm{N}$ in latitude and $6^{\circ} 28^{\prime} \mathrm{W}$ and $3^{\circ} 00^{\prime} \mathrm{E}$ in longitude (Salomon and Breton 1991, 1993). It is a submodel with a mesh size of one square nautical mile, inserted inside a more global one of the whole North-West European shelf, which provides boundary conditions (i.e. tidal amplitude and phase).

Hydrodynamic equations are solved using an alternate-direction-implicit finite difference method. The model computes instantaneous and residual velocities and trajectories for different tide and wind conditions through the 'barycentric technique' detailed by Salomon et al. $(1988,1996)$. This takes into account only the two main tidal components (i.e. the lunar component M2 and the solar component S2) and assumes a uniform wind stress over the whole area.

The transport and mixing of planktonic larvae are simulated by solving the advection-diffusion equation below, using the residual velocities obtained from the hydrodynamic model:

$$
\begin{aligned}
\frac{\partial(H C)}{\partial t}+ & \frac{\partial(H u C)}{\partial x}+\frac{\partial(H v) C}{\partial y} \\
& -\frac{\partial^{2}\left(K H \frac{\partial C}{\partial x}\right)}{\partial x}-\frac{\partial^{2}\left(K H \frac{\partial C}{\partial y}\right)}{\partial y}=0
\end{aligned}
$$

with $C$, the larval concentration at any point in space and time (individuals $\mathrm{m}^{-3}$ ), $u$ and $v$, the residual velocity components in the $x$ and $y$ directions, respectively, $H$, the average water depth over a tidal cycle, and $K$, the coefficient of turbulent diffusion.

The coefficient of turbulent diffusion was estimated according to Elder's law as (Salomon and Breton 1993):

$K=\beta U H$

with $\beta$, a proportionality coefficient fixed to $0.3, U$, the average instantaneous current velocity, and $H$, the average water depth.

\section{Biological inputs}

The compilation of historical records on the location of $O$. fusiformis from 1950 to 2001 at different seasons in the English Channel shows that it could be present in all fine sediment areas and locally observed in coarse sediments (Fig. 1). However, several observations carried out over a single year, both in several bays including the eastern Bay of Seine (Dauvin and Gillet 1991; Thiébaut et al. 1997) and in the whole English Channel (A.S. Barnay et al., personal observation), indicated that adults occur mainly as dense patches within fine and muddy sand. Consequently, we distinguished 19 spawning areas assumed to be discrete adult populations (Fig. 2).

Adult habitat, defined as favourable areas for the development of settlers, was established according to the distribution of fine sediments (Larsonneur et al. 1982) and muddy fine sand benthic communities (Holme 1966; Cabioch 1968; Cabioch and Glaçon 1975, 1977; Gentil and Cabioch 1997) (Fig. 2).

For each population, the quantity of released larvae per square metre was a function of the mean adult density (ind. $\mathrm{m}^{-2}$ ), the sex ratio, the proportion of mature females and the average fecundity. Mean adult density varied among populations and was established from previous unpublished and published data (see Table 1). The sex ratio was equal to 1 (Gentil et al. 1990). As the smallest adults do not mature (Gentil et al. 1990), we assume a proportion of $70 \%$ of reproductive individuals in the absence of size-frequency data. The average effective fecundity was fixed to 40,000 ovocytes per female (Thiébaut and Dauvin 1991). The main characteristics of the biological inputs are summarised in Table 1 . 


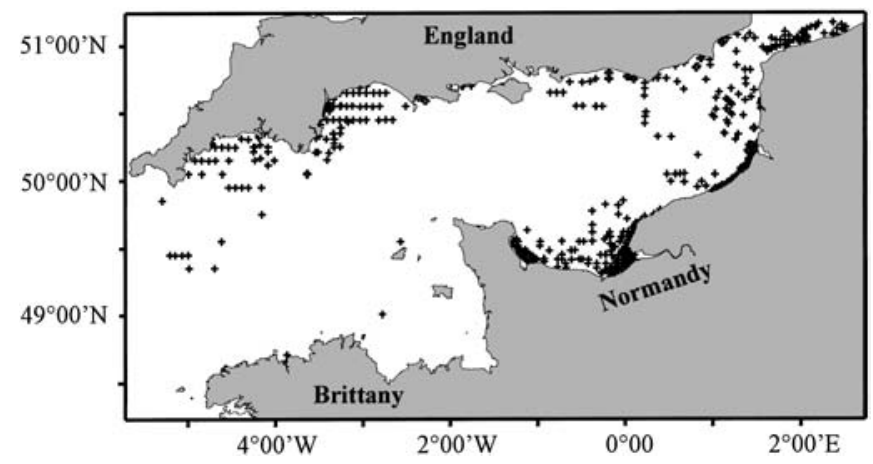

Fig. 1 Distribution of the polychaete Owenia fusiformis in the English Channel. From Holme (1950, 1953), Probert (1975), Dauvin (1984), Dewarumez et al. (1992), Thiébaut et al. (1997), Parry et al. (1999), Newell et al. (2001), L. Cabioch (personal communication), J.C. Dauvin (personal communication), A.S. Barnay, F. Gentil and E. Thiébaut (personal observation)

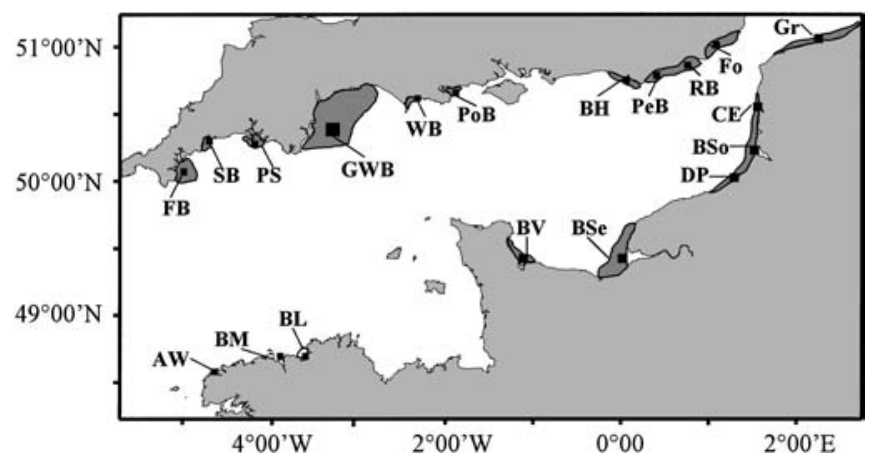

Fig. 2 Location of adult habitat of Owenia fusiformis in the English Channel. Spawning area for each population is indicated by a square. $A W$ Aber Wrac'h, $B M$ Bay of Morlaix, $B L$ Bay of Lannion, $B V$ Bay of Veys, $B S e$ eastern Bay of Seine, DP Dieppe, BSo Bay of Somme, $C E$ Canche estuary, $G r$ Gravelines, $F B$ Falmouth Bay, $S B$ St Austell Bay, PS Plymouth Sound, GWB Great West Bay, WB Weymouth Bay, $P o B$ Poole Bay, $B H$ Beachy Head, $P e B$ Pevensey Bay, $R B$ Rye Bay, Fo Folkestone
Table 1 Characteristics of the different Owenia fusiformis populations in the English Channel

\begin{tabular}{lcccc}
\hline Population & $\begin{array}{l}\text { Size of adult } \\
\text { habitat }\left(\mathrm{km}^{2}\right)\end{array}$ & $\begin{array}{l}\text { Size of spawning } \\
\text { area }\left(\mathrm{km}^{2}\right)\end{array}$ & $\begin{array}{l}\text { Adult density } \\
\left.\text { (ind. } \mathrm{m}^{-2}\right)\end{array}$ & $\begin{array}{c}\text { Larval release } \\
\left(10^{4} \text { ind. } \mathrm{m}^{-2}\right)\end{array}$ \\
\hline Aber Wrac'h & 3.4 & 3.4 & 1 & 1.4 \\
Bay of Morlaix & 3.4 & 3.4 & 5 & 7 \\
Bay of Lannion & 17.2 & 6.9 & 2.5 & 3.5 \\
Bay of Veys & 165.3 & 34.4 & 41 & 57.4 \\
Eastern Bay of Seine & 544.1 & 34.4 & 354 & 495.6 \\
Dieppe & 172.2 & 34.4 & 6 & 8.4 \\
Bay of Somme & 155 & 34.4 & 2.5 & 3.5 \\
Bay of Canche & 124 & 34.4 & 2.5 & 3.5 \\
Gravelines & 223.8 & 34.4 & 2.5 & 12.6 \\
Falmouth Bay & 144.6 & 31 & 5 & 3.5 \\
St Austell Bay & 58.5 & 17.2 & 3 & 4.2 \\
Plymouth Sound & 471.8 & 55.1 & 8.5 & 12 \\
Great West Bay & 1811.5 & 68.9 & 2.5 & 3.5 \\
Weymouth Bay & 34.4 & 10.3 & 2.5 & 3.5 \\
Poole Bay & 41.3 & 10.3 & 4 & 5.6 \\
Beachy Head & 79.2 & 20.6 & 2.5 & 3.5 \\
Pevensey Bay & 151.5 & 10.3 & 4 & 5.6 \\
Rye Bay & 241 & 24.1 & 12 & 16.8 \\
Folkestone & 193.3 & 17.2 & & 7 \\
\hline
\end{tabular}

\section{Simulations}

Larval dispersal was simulated for a period of one month according to $O$. fusiformis larval life span determined from laboratory cultures (Wilson 1932) or from field observations (Thiébaut et al. 1992). All the simulations were made for an average tide with or without a moderate constant wind of $6 \mathrm{~m} \mathrm{~s}^{-1}$. The choice of an average tide results from previous simulations, which showed no effect of the lunar tidal cycle on larval dispersal (Ellien 2001; C. Ellien, E. Thiébaut, F. Dumas, J.C. Salomon and P. Nival, unpublished results). Two wind directions corresponding to the prevailing winds in the English Channel during the $O$. fusiformis spawning period were considered: NE (direction $45^{\circ}$ ) and SW (direction $\left.225^{\circ}\right)$.

As this study is mainly concerned with patterns of potential larval dispersal and relative differences in the origin of settlers according to environmental forcing, larval mortality was set to 0 .

For each population, three parameters were calculated at the end of larval dispersal:
1. the retention rate, equal to the ratio between the number of released larvae and the number of larvae settling on the adult habitat of the parental population;

2. the colonisation rate, equal to the ratio between the number of released larvae and the number of larvae settling on the adult habitat of distant populations;

3. the density of settlers (ind. $\mathrm{m}^{-2}$ ).

Retention and colonisation rates were considered to be zero when settlement was less than 1 ind. $\mathrm{m}^{-2}$. 
Table 2 Influence of wind forcing on larval retention and colonisation rates (in \%) for the different Owenia fusiformis populations in the English Channel

\begin{tabular}{|c|c|c|c|c|c|c|}
\hline \multirow[t]{2}{*}{ Population } & \multicolumn{2}{|l|}{ No wind } & \multicolumn{2}{|c|}{ SW wind of $6 \mathrm{~m} \mathrm{~s}^{-1}$} & \multicolumn{2}{|c|}{$\mathrm{NE}$ wind of $6 \mathrm{~m} \mathrm{~s}^{-1}$} \\
\hline & Retention rate & Colonisation rate & Retention rate & Colonisation rate & Retention rate & Colonisation rate \\
\hline Aber Wrac'h & 0 & $16.10^{-3}$ & 0 & 0.04 & 0 & 0 \\
\hline Bay of Morlaix & $6.10^{-3}$ & 1.5 & $36.10^{-4}$ & 1.1 & $14.10^{-3}$ & 1.6 \\
\hline Bay of Lannion & 5.58 & $19.10^{-4}$ & 3.45 & 0 & 3.66 & $7.10^{-3}$ \\
\hline Bay of Veys & 0.15 & 0 & 0.16 & 0 & 0.11 & 0 \\
\hline Eastern Bay of Seine & 34.46 & $21.10^{-4}$ & 19.08 & 0 & 2.82 & 0.8 \\
\hline Dieppe & 18.99 & 3.4 & 3.75 & 21.1 & 3.02 & $41.10^{-3}$ \\
\hline Bay of Somme & 19.04 & 7.4 & 6.32 & 7.9 & 0.97 & 18.7 \\
\hline Bay of Canche & 1.66 & $73.10^{-3}$ & 0.08 & 2.1 & 6.01 & 9.0 \\
\hline Gravelines & 0.73 & $24.10^{-4}$ & 0.13 & 0 & 0 & 2.8 \\
\hline Falmouth Bay & 1.26 & 0 & 14.36 & 2.9 & 0 & 0 \\
\hline St Austell Bay & 10.23 & 13.7 & 5.53 & 15.1 & 0.55 & 6.3 \\
\hline Plymouth Sound & 12.46 & 0.9 & 6.27 & 6.8 & 2.34 & 13.9 \\
\hline Great West Bay & 80.91 & 0 & 49.57 & $23.10^{-3}$ & 9.11 & $78.10^{-3}$ \\
\hline Weymouth Bay & 1.19 & 2.6 & 2.52 & $82.10^{-3}$ & 0.47 & 24.3 \\
\hline Poole Bay & 6.00 & $1.10^{-2}$ & 4.58 & 0 & 2.71 & 0.3 \\
\hline Beachy Head & 3.36 & 0.3 & 0.04 & 14.0 & 1.74 & 0 \\
\hline Pevensey Bay & 2.68 & 5.0 & 0 & 3.2 & 0 & 3.9 \\
\hline Rye Bay & 6.25 & 7.4 & 0 & 0.7 & $36.10^{-3}$ & 3.6 \\
\hline Folkestone & 5.58 & 0.1 & 0.08 & 0 & 0 & 3.2 \\
\hline
\end{tabular}

\section{Results}

Effects of tidal residual and wind-induced currents on larval retention and colonisation

Without wind, larval retention rate varies strongly among $O$. fusiformis populations, from $0 \%$ off the Aber Wrac'h to $80.9 \%$ in Great West Bay (Table 2). Larval retention is significantly correlated with the size of adult habitat and the mean velocity of tidal residual currents, so that it is maximum when the size of adult habitat is maximum and when mean current velocity is minimum [Retention rate $=0.864$ (Habitat size) -0.185 (Mean velocity) $+7.564 ; R^{2}=0.91 ; n=19 ; P<0.001$ ) (Fig. 3). This relation remains when the Great West Bay population characterised by a very large habitat is removed.

For the majority of populations (i.e. 11 out of 19), larval colonisation rate is lower than retention rate and does not exceed $1 \%$ of larval release, so that most larvae which are transported away from the parental population are lost (Table 2). In two populations (i.e. Dieppe and the Bay of Somme), colonisation rates which remain below retention rate strongly increase the likelihood of larvae settling on a suitable substrate. Only six populations show colonisation rates greater than retention rates.

Wind-induced currents greatly modify larval dispersal patterns and consequently larval retention and colonisation rates (Table 2). In most populations, wind increases the velocity of residual currents, and induces a general decrease in larval retention rate, which can even become zero, whatever the wind direction. However, the magnitude of this decrease varies according to wind direction and is generally higher for a NE wind. In three populations, the influence of wind forcing is a function of its

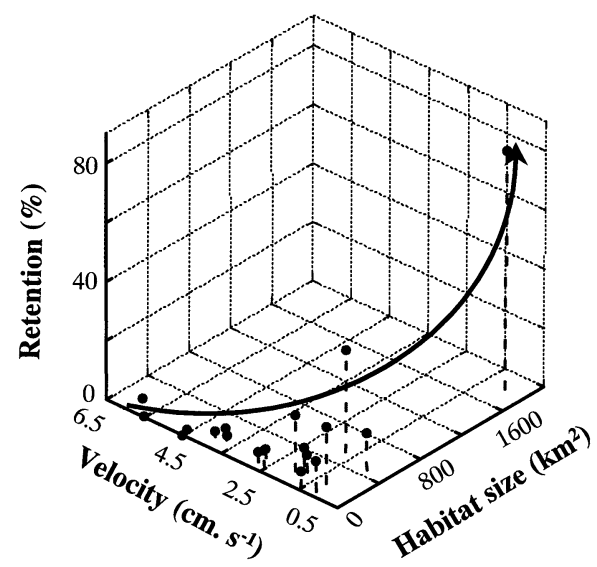

Fig. 3 Influence of tidal residual current velocity and adult habitat size on Owenia fusiformis larval retention rate

direction. In Falmouth Bay and Weymouth Bay, a SW wind increases larval retention rate while a NE wind weakens it. Conversely, in the Bay of Canche, retention rate is enhanced by a NE wind and reduced by a SW wind. In the bays of Veys and Morlaix, it remains unchanged with or without the action of the wind. Off the Aber Wrac'h, no retention occurs, whatever the meteorological conditions.

Relative to the case with no wind, colonisation rates tend to remain basically unchanged or increase (Table 2). Thus, wind action compensates partly or totally for the decrease in larval retention and limits larval export onto unsuitable substrates. On the other hand, in a few populations, larval colonisation is reduced for one wind direc- 
Table 3 Influence of wind forcing on the density and origin of settlers for the different Owenia fusiformis populations in the English Channel. Allochthonous supply rate gives the proportion of settlers from an external origin (in \%)

\begin{tabular}{|c|c|c|c|c|c|c|c|c|c|}
\hline \multirow[t]{3}{*}{ Population } & \multicolumn{3}{|l|}{ No wind } & \multicolumn{3}{|c|}{ SW wind of $6 \mathrm{~m} \mathrm{~s}^{-1}$} & \multicolumn{3}{|c|}{$\mathrm{NE}$ wind of $6 \mathrm{~m} \mathrm{~s}^{-1}$} \\
\hline & \multicolumn{2}{|c|}{$\begin{array}{l}\text { Settlers density } \\
\text { (ind. } \mathrm{m}^{-2} \text { ) }\end{array}$} & \multirow[t]{2}{*}{$\begin{array}{l}\text { Allochthonous } \\
\text { supply rate }\end{array}$} & \multicolumn{2}{|c|}{$\begin{array}{l}\text { Settlers density } \\
\text { (ind. } \mathrm{m}^{-2} \text { ) }\end{array}$} & \multirow[t]{2}{*}{$\begin{array}{l}\text { Allochthonous } \\
\text { supply rate }\end{array}$} & \multicolumn{2}{|c|}{$\begin{array}{l}\text { Settlers density } \\
\text { (ind. } \mathrm{m}^{-2} \text { ) }\end{array}$} & \multirow[t]{2}{*}{$\begin{array}{l}\text { Allochthonous } \\
\text { supply rate }\end{array}$} \\
\hline & $\begin{array}{l}\text { Local } \\
\text { origin }\end{array}$ & $\begin{array}{l}\text { External } \\
\text { origin }\end{array}$ & & $\begin{array}{l}\text { Local } \\
\text { origin }\end{array}$ & $\begin{array}{l}\text { External } \\
\text { origin }\end{array}$ & & $\begin{array}{l}\text { Local } \\
\text { origin }\end{array}$ & $\begin{array}{l}\text { External } \\
\text { origin }\end{array}$ & \\
\hline Aber Wrac'h & 0 & 0 & - & 0 & 0 & - & 0 & 0 & - \\
\hline Bay of Morlaix & 4.2 & 2.8 & 39.9 & 2.5 & 2.4 & 49.0 & 9.9 & 4.9 & 33.1 \\
\hline Bay of Lannion & 773 & 213 & 21.6 & 477 & 155 & 24.5 & 506 & 229 & 31.2 \\
\hline Bay of Veys & 179 & 21 & 10.5 & 196 & 0 & 0 & 130 & 8,385 & 98.5 \\
\hline Eastern Bay of Seine & 107,977 & 0 & 0 & 59,787 & 0 & 0 & 8,822 & 2.2 & 0.02 \\
\hline Dieppe & 3198 & 152 & 4.5 & 633 & 4 & 0.6 & 508 & 1395 & 73.3 \\
\hline Bay of Somme & 1,471 & 627 & 29.9 & 489 & 2,596 & 84.1 & 75 & 606 & 89.0 \\
\hline Bay of Canche & 161 & 1,096 & 87.2 & 7.3 & 2,676 & 99.7 & 582 & 733 & 55.7 \\
\hline Gravelines & 140 & 8 & 5.4 & 26 & 205 & 88.7 & 0 & 0 & - \\
\hline Falmouth Bay & 95 & 1,180 & 92.5 & 1,083 & 2.7 & 0.2 & 0 & 1,521 & 100 \\
\hline St Austell Bay & 2,103 & 226 & 9.7 & 1,134 & 522 & 31.5 & 113 & 3,010 & 96.4 \\
\hline Plymouth Sound & 610 & 0 & 0 & 307 & 385 & 55.6 & 115 & 14 & 10.9 \\
\hline Great West Bay & 3,694 & 6 & 0.2 & 2,263 & 87 & 3.7 & 416 & 48 & 10.3 \\
\hline Weymouth Bay & 125 & 1 & 0.8 & 264 & 55 & 17.2 & 50 & 37 & 42.5 \\
\hline Poole Bay & 523 & 0 & 0 & 399 & 2.7 & 0.7 & 236 & 0 & 0 \\
\hline Beachy Head & 488 & 2 & 0.4 & 6.4 & 0 & 0 & 252 & 913 & 78.4 \\
\hline Pevensey Bay & 64 & 574 & 90.0 & 0 & 224 & 100.0 & 0 & 347 & 100.0 \\
\hline Rye Bay & 350 & 51 & 12.7 & 0 & 263 & 100.0 & 2 & 223 & 99.1 \\
\hline Folkestone & 837 & 177 & 17.5 & 13 & 203 & 94.0 & 0 & 38 & 100.0 \\
\hline
\end{tabular}

Fig. 4 Influence of wind forcing on the variation of settlers' density and origin: settlers from a local origin (empty column), settlers from an external origin (filled column)
Bay of Lannion

Falmouth Bay

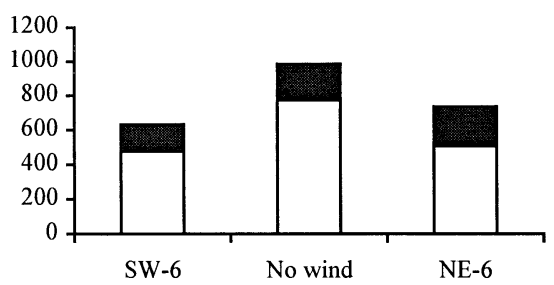

Bay of Veys

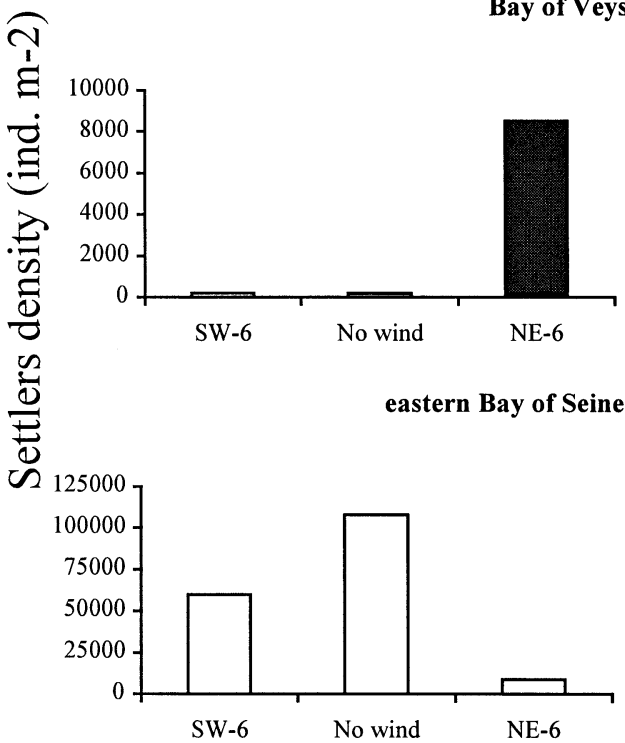

Wind forcing

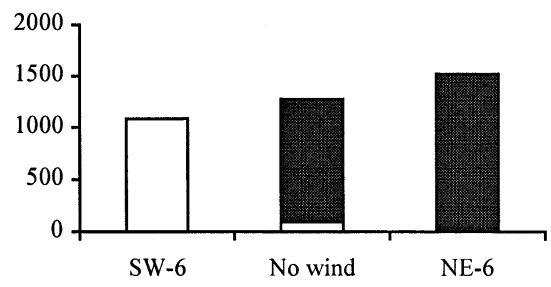

Pevensey Bay

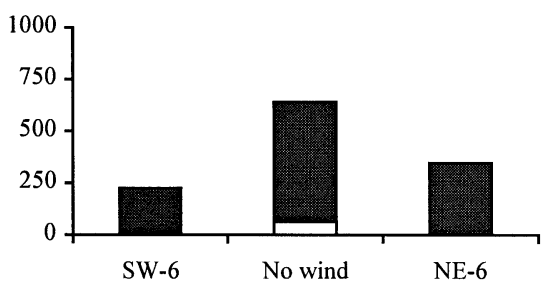

Bay of Somme

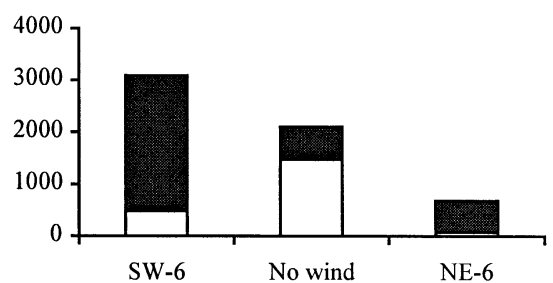

Wind forcing 

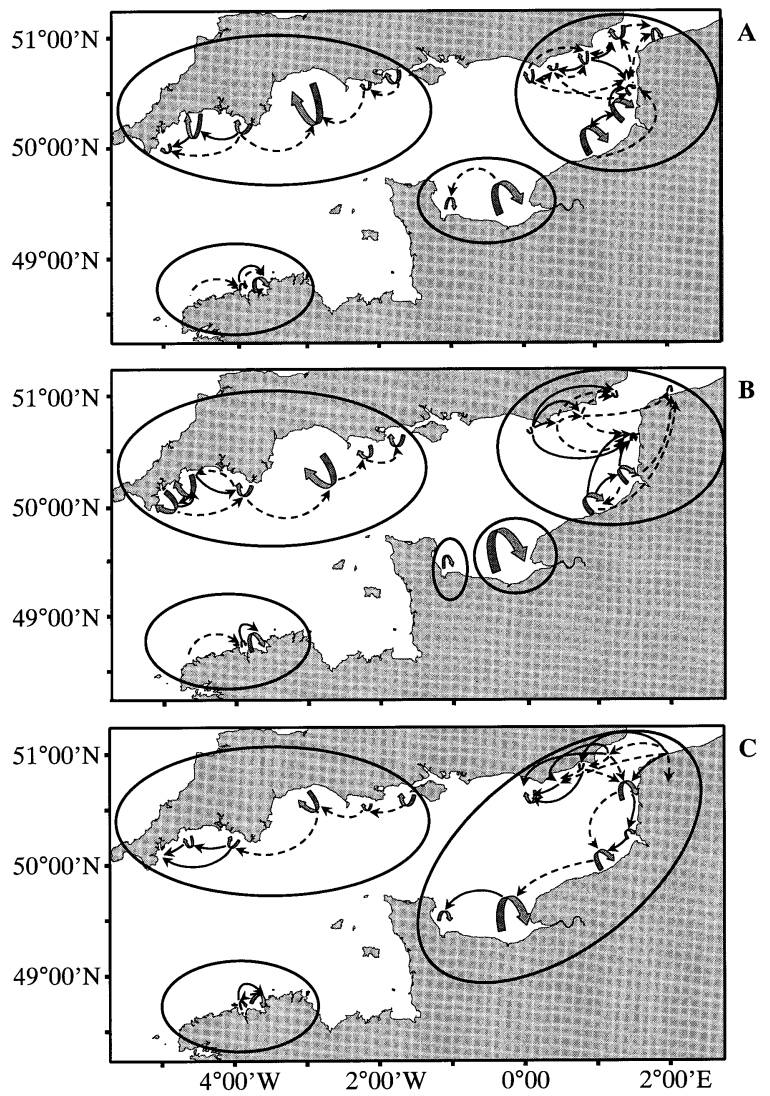

Fig. 5 Larval retention and exchange between Owenia fusiformis populations in the English Channel for three hydrodynamic conditions: A average tide, $\mathbf{B}$ average tide and SW wind of $6 \mathrm{~m} \mathrm{~s}^{-1}$, $\mathbf{C}$ average tide and $\mathrm{NE}$ wind of $6 \mathrm{~m} \mathrm{~s}^{-1}$. Retention (curved grey arrow), larval exchange $<100$ ind. $\mathrm{m}^{-2}$ (dotted arrow), larval exchange $\geq 100$ ind. $\mathrm{m}^{-2}$ (continuous arrow)

tion (e.g. Weymouth Bay) or for both wind directions (e.g. Rye Bay).

Effects of tidal residual and wind-induced currents on the density and origin of settlers

Except for the Aber Wrac'h population, for which larval supply is zero whatever the meteorological conditions, settlers' densities and origin fluctuate between populations and as a function of wind forcing (Table 3). Thus, within a population, variation in the density of settlers can reach one or two orders of magnitude in relation to wind conditions. While the relative importance of local vs external larval supply varies greatly for most populations, only four populations (e.g. Great West Bay, eastern Bay of Seine) are self-sustained with or without wind. Conversely, settlement in Pevensey Bay results mainly from larval colonisation whatever the meteorological conditions.

Among populations, five patterns can be identified according to the extent of variation in the densities and origin of settlers (see Fig. 4):
1. low variation in the density of settlers with weak fluctuations in the origin of larval supply (e.g. Bay of Lannion);

2. low variation in settlers' densities with large fluctuations in the origin of larvae (e.g. Falmouth Bay);

3. large variation in settlers' densities in relation to large variation of larval supply from distant populations (e.g. Bay of Veys, Pevensey Bay);

4. large variation in settlers' densities in relation to large variation of local larval supply (e.g. eastern Bay of Seine);

5. large variation in settlers' densities due to large variation of larval supply from the local and distant populations (e.g. Bay of Somme).

\section{Larval exchanges among populations}

In response to larval drift, larval exchanges occur mainly between neighbouring populations except in the eastern English Channel where geographical distances between populations are shorter (Fig. 5). Larvae released at one site may colonise up to four distant populations (i.e. Beachy Head with a SW wind) while one site may receive larvae from up to six different populations (i.e. Bay of Canche with a SW wind).

Without wind, four groups of interconnected populations are identified: (1) along the northern coasts of Brittany, (2) populations of the Bay of Veys and the eastern Bay of Seine, (3) along the south-western coasts of England, and (4) in the eastern English Channel (Fig. 5a). While wind-induced currents greatly influence larval retention rates and the intensity of larval exchanges, the degree of connectivity between local populations is only slightly affected. In the case of a SW wind, the only difference is the lack of larval exchange between the Bay of Veys and the eastern Bay of Seine (Fig. 5b). By contrast, for a NE wind, the assemblage including the populations of the Bay of Veys and the eastern Bay of Seine is linked to the assemblage composed of the populations located in the eastern English Channel (Fig. 5c).

\section{Discussion}

Quantifying rates of larval supply to potential settlement sites and identifying the relative origin of settlers remain a major challenge in studies on population dynamics of benthic invertebrates (Eckman 1996). Although the recent development of numerical models provides some of the most relevant results (e.g. Tremblay et al. 1994; Young et al. 1998), it requires a sufficiently accurate circulation model including mesoscale features and, if necessary, larval behaviour (Eckman 1996).

In the present study, the use of a depth-averaged hydrodynamic model integrating tides and wind-induced currents is acceptable at the scale of the whole English Channel because of the weakness of density gradients (Salomon and Breton 1991, 1993). For most of the study 
area, the model provided a substantially realistic representation of the flow field, which was validated by comparing simulated and observed patterns of radionuclide transport in the English Channel (Guéguéniat et al. 1993). Dispersal can also be affected by larval vertical distribution, and Thiébaut et al. (1992) showed that the vertical distribution of $O$. fusiformis larvae was related to water-column stratification. However, because of the intense tidal mixing over the most of the study area, one can assume that larvae are passively carried particles. Furthermore, even in the eastern Bay of Seine where density gradients are present, a broad agreement occurs between predicted dispersal and field distributions of O. fusiformis larvae (C. Ellien and E. Thiébaut, personal observation). Such observations suggest that simulations, which are only approximating reality, may be useful in analysing the processes involved in larval transport and settlement.

Simulations indicated that wind forcing has a strong influence on larval dispersal patterns and the magnitude of exchanges between populations, and could be responsible for supplying populations with larvae of different origin. Without wind, the level of larval retention indicated that self-seeding was the principal mechanism involved in the maintenance of most $O$. fusiformis populations except for those located in the Bay of Canche, Falmouth Bay and Pevensey Bay. Under moderate wind conditions, larval supply from distant populations generally exceeded local supply, so that the potential for selfsustainability is probably low and a large number of populations can be defined as demographically 'open'. For a few populations (e.g. Bay of Somme), settlement depends almost entirely on larval supply from distant populations. Larval retention can be the dominant process for repopulation whatever the wind conditions for just four populations (e.g. Bay of Lannion, eastern Bay of Seine).

As previously reported for other marine invertebrates, wind-induced currents also have a significant effect on the densities of settlers which, in the case of $O$. fusiformis, may vary by as much as two orders of magnitude according to the inter-annual variability in wind direction and strength at the time of larval release. For example, temporal variations in the settlement of the barnacle Semibalanus balanoides in Narragansett Bay (Rhode Island, USA) was strongly correlated to wind forcing from daily to annual scales (Bertness et al. 1996). Likewise, Young et al. (1998) highlighted from a modelling study, that inter-annual variability in wind-driven transport of larvae could be causing large year-to-year variation in the settlement of cockles and mussels in The Wash (England). All these studies were performed at a local scale and tended to oppose favourable vs unfavourable meteorological conditions for larval settlement. By contrast, at a regional scale, our simulations suggest that variation in wind forcing can affect $O$. fusiformis populations differently. Settlement intensity did not covary, even between adjacent populations, and no spatial pattern in recruitment could be determined. For example, currents driven by a NE wind of $6 \mathrm{~m} \mathrm{~s}^{-1}$ produced a 12 -fold decrease in the number of successfully settling larvae in the eastern Bay of Seine but a 42-fold increase in the Bay of Veys, when compared with tidal forcing alone. Similarly, for a SW wind of $6 \mathrm{~m} \mathrm{~s}^{-1}$, there was a five-fold decrease in the density of settlers off Dieppe whereas it was enhanced by a factor of 1.5 in the Bay of Somme.

While numerous studies have emphasised larval supply limitation in the regulation of rocky shore population abundances (e.g. Gaines and Roughgarden 1985; Roughgarden et al. 1988; Carroll 1996), its influence on soft sediments is still debated. In a recent review, Olafsson et al. (1994) concluded that settlement rate is not necessarily an accurate predictor of recruitment and that post-settlement processes could be more determinant. On the other hand, Young et al. (1998) suggested that settlement success could contribute to inter-annual variation in the recruitment of exploited bivalves in The Wash. Concerning O. fusiformis populations in the English Channel, our results raise two questions:

1. what is the accuracy of simulated settlers' densities, given that larval mortality was set to 0 and that reproductive output was crudely estimated?

2. what is the density of settlers required for the maintenance of a population?

Estimations of larval mortality varied greatly among meroplanktonic organisms or among regions for one species (Rumrill 1990). While Hill (1990) emphasised the minor role of larval mortality compared to hydrodynamics on larval losses on the northwestern European continental shelf, Cowen et al. (2000) argued that this biological parameter may greatly affect both the extent of larval exchanges and the density of settling larvae. Data on $O$. fusiformis settlement are limited and are only available in the eastern Bay of Seine. During a year of good settlement, the range of maximal densities of settlers in three stations off the Seine estuary in June 1987 (i.e. 21,700-268,400 ind. $\mathrm{m}^{-2}$ ) (Dauvin 1992) was similar to that predicted under either tidal forcing alone or for a SW wind of $6 \mathrm{~m} \mathrm{~s}^{-1}\left(59,800-108,000\right.$ ind. $\left.\mathrm{m}^{-2}\right)$. Such a result seems to indicate that larval mortality has probably a minor role on the extent of $O$. fusiformis settlement if no spatial or temporal variation in mortality is assumed.

At the same stations off the Seine estuary, the comparison between the density of settlers and recruits in June 1987 and February 1988 (Dauvin 1992; Dauvin and Gillet 1991) indicated that post-settlement mortality fluctuated between $98.0 \%$ and $99.8 \%$ over 8 months. Although the mortality of settlers could be density dependent and variable in space (Dauvin 1992), a 99\% mortality rate suggests that the density of settlers needs to reach several hundred individuals per square metre in order to sustain an adult population of less than 10 ind. $\mathrm{m}^{-2}$. Indeed, it should exceed tens of thousands (ind. $\mathrm{m}^{-2}$ ) to sustain the main population of the eastern Bay of Seine. According to these estimations, simulations 
showed that larval supply may be limiting for some populations (e.g. eastern Bay of Seine, Beachy Head) under some meteorological conditions and may be partly responsible for large inter-annual variation in the abundance of recruits as observed in the eastern Bay of Seine (Ménard et al. 1989; Dauvin and Gillet 1991).

As larval exchange mainly occurs between neighbouring populations, no significant exchange was observed for distances exceeding $100 \mathrm{~km}$. Consequently, three groups of interconnected populations (i.e. eastern English Channel, southwestern coasts of England and northern coasts of Brittany) were recognised and may be considered as metapopulations according to the definition of Botsford et al. (1994) as: 'a number of subpopulations of adults distributed along a coast, linked by dispersal of a planktonic larval stage'. The term 'metapopulation' was introduced by Levins (1969) to define a spatially structured population of populations which persists through a balance between local extinction and recolonisation according to three assumptions: (1) population habitats have equal size and are equally isolated, (2) local populations have independent dynamics and (3) migration rate among local populations is low and has no real effect on their own dynamics. In practice, no metapopulation completely matches this model and a broadly defined concept has been proposed (Hanski and Simberloff 1997; Harrison and Taylor 1997). However, two different aspects of marine population dynamics must be underlined in order to apply the metapopulation concept (Caley et al. 1996). First, most local marine populations are persistent and do not suffer from frequent extinctions. Second, marine invertebrates with planktonic larvae may exhibit high dispersal abilities and migration rates. Nevertheless, assuming two key features, which are the spatial structure in discrete local breeding populations and their connection through migration affecting local dynamics, such a concept may remain quite useful in explaining marine population dynamics. While most studies on larval dispersal have focused on a single population, the results provided by our simulations highlight the importance of exchanges among connected populations on the fluctuation in settlement rates. They suggest that the local dynamics of most populations may be understood at a higher level of organisation in the light of inter-annual variation in the direction and magnitude of larval exchanges.

Acknowledgements This work was carried out within the French National Programme 'Programme National d'Environnement Côtier' (PNEC-ART2), supported by CNRS-INSU and IFREMER. We thank Dr. Louis Cabioch (Station Biologique de Roscoff) and Prof. Jean-Claude Dauvin (Station Marine de Wimereux) for providing unpublished data on the distribution of Owenia fusiformis in the English Channel. We are grateful to Taimour Jolly (Station Biologique de Roscoff) for the English proofreading.

\section{References}

Bertness MD, Gaines SD, Wahle RA (1996) Wind-driven settlement patterns in the acorn barnacle Semibalanus balanoides. Mar Ecol Prog Ser 137:103-110

Botsford LW, Moloney CL, Hastings A, Largier JL, Powell TM, Higgins K, Quinn JF (1994) The influence of spatially and temporally varying oceanographic conditions on meroplanktonic metapopulations. Deep Sea Res II 41:107-145

Botsford LW, Wing SR, Largier JL (1998) Population dynamics and management implications of larval dispersal. S Afr J Mar Sci 19:131-142

Cabioch L (1968) Contribution à la connaissance des peuplements benthiques de la Manche occidentale. Cah Biol Mar 9:493-720

Cabioch L, Glaçon R (1975) Distribution des peuplements benthiques en Manche orientale, de la Baie de Somme au Pas de Calais. C R Acad Sci Paris 280:491-494

Cabioch L, Glaçon R (1977) Distribution des peuplements benthiques en Manche orientale, du cap d'Antifer à la Baie de Somme. C R Acad Sci Paris 285:209-212

Cabioch L, Gentil F, Glaçon R, Retière C (1977) Le macrobenthos des fonds meubles de la Manche: distribution générale et écologie. In: Keegan BF, O'Ceidigh P, Boaden PJS (eds) Biology of benthic organisms. Proceedings of the 11th European marine biology symposium. Pergamon, Oxford, pp 115-128

Caley MJ, Carr MH, Hixon MA, Hughes TP, Jones GP, Menge BA (1996) Recruitment and the local dynamics of open marine populations. Annu Rev Ecol Syst 27:477-500

Carroll ML (1996) Barnacle population dynamics and recruitment regulation in southcentral Alaska. J Exp Mar Biol Ecol 199: 285-302

Cowen RK, Lwiza KMM, Sponaugle S, Paris CB, Olson DB (2000) Connectivity of marine populations: open or closed? Science 287:857-859

Dauvin JC (1984) Dynamique d'écosystèmes macrobenthiques des fonds sédimentaires de la Baie de Morlaix et leur perturbation par les hydrocarbures de l'Amoco Cadiz. Thèse d'état, Université Paris VI

Dauvin JC (1992) Cinétique du recrutement et croissance des juvéniles d'Owenia fusiformis Delle Chiaje en baie de Seine (Manche orientale). Oceanol Acta 15:187-196

Dauvin JC, Gillet P (1991) Spatio-temporal variability in population structure of Owenia fusiformis Delle Chiaje (Annelida: Polychaeta) from the Bay of Seine (eastern English Channel). J Exp Mar Biol Ecol 152:105-122

Dewarumez JM, Davoult D, San Vincente-Anorve EL, Frontier S (1992) Is the muddy heterogeneous sediment assemblage an ecotone between the pebbles community and the Abra alba community in the Southern Bight of the North Sea? Neth J Sea Res 30:229-238

Eckman JE (1996) Closing the larval loop: linking larval ecology to the population dynamics of marine benthic invertebrates. J Exp Mar Biol Ecol 200:207-237

Ellien C (2001) Modélisation du transport larvaire en Manche et conséquences sur le recrutement d'invertébrés à cycle benthopélagique. Importance relative des processus biologiques et hydrodynamiques. $\mathrm{PhD}$ thesis. Université Paris VI

Ellien C, Thiébaut E, Barnay AS, Dauvin JC, Gentil F, Salomon JC (2000) The influence of variability in larval dispersal on the dynamics of a marine metapopulation in the eastern Channel. Oceanol Acta 23:423-442

Gaines SD, Roughgarden J (1985) Larval settlement rate: a leading determinant of structure in an ecological community of the marine intertidal zone. Proc Natl Acad Sci USA 82:3707-3711

Gentil F, Cabioch L (1997) Carte des peuplements macrobenthiques de la Baie de Seine et Manche centrale sud. Editions Station Biologique de Roscoff, Roscoff

Gentil F, Dauvin JC, Ménard F (1990) Reproductive biology of the polychaete Owenia fusiformis Delle Chiaje in the Bay of Seine (eastern English Channel). J Exp Mar Biol Ecol 142:13-23

Guéguéniat P, Salomon JC, Wartel M, Cabioch L, Fraizier A (1993) Transfer pathways and transit time of dissolved matter 
in the eastern English Channel indicated by space-time radiotracer measurements and hydrodynamic modelling. Est Coast Shelf Sci 36:477-494

Hanski IA, Simberloff D (1997) The metapopulation approach, its history, conceptual domain, and application to conservation. In: Hanski IA, Gilpin ME (eds) Metapopulation biology: ecology, genetics and evolution. Academic Press, San Diego, pp 5-26

Harrison S, Taylor AD (1997) Empirical evidence for metapopulation dynamics. In: Hanski IA, Gilpin ME (eds) Metapopulation biology: ecology, genetics and evolution. Academic Press, San Diego, pp 27-42

Hill AE (1990) Pelagic dispersal of Norway lobster Nephrops norvegicus larvae examined using an advection-diffusion-mortality model. Mar Ecol Prog Ser 64:217-226

Holme NA (1950) The bottom fauna of Great West Bay. J Mar Biol Assoc UK 29:163-183

Holme NA (1953) The biomass of the bottom fauna in the English Channel off Plymouth. J Mar Biol Assoc UK 32:1-49

Holme NA (1966) The bottom fauna of the English Channel. Part II. J Mar Biol Assoc UK 46:401-493

Incze LS, Naimie CE (2000) Modelling the transport of lobster (Homarus americanus) larvae and postlarvae in the Gulf of Maine. Fish Oceanogr 9:99-113

Larsonneur C, Bouysse P, Auffret JP (1982) The superficial sediments of the English Channel and its western approaches. Sedimentology 29:851-864

Levins R (1969) Some demographic and genetic consequences of environmental heterogeneity for biological control. Bull Entomol Soc Am 15:237-240

Ménard F, Gentil F, Dauvin JC (1989) Population dynamics and secondary production of Owenia fusiformis Delle Chiaje (Polychaeta) from the Bay of Seine (eastern English Channel). J Exp Mar Biol Ecol 133:151-167

Newell RC, Seiderer LJ, Robinson JE (2001) Animal:sediment relationships in coastal deposits of the eastern English Channel. J Mar Biol Assoc UK 81:1-9

Olafsson EB, Peterson CH, Ambrose WGJ (1994) Does recruitment limitation structure populations and communities of macro-invertebrates in marine soft sediments: the relative significance of pre-and post-settlement processes. Oceanogr Mar Biol Annu Rev 32:65-109

Parry DM, Kendall MA, Rowden AA, Widdicombe S (1999) Species body size distribution patterns of marine benthic macrofauna assemblages from contrasting sediment types. J Mar Biol Assoc UK 79:793-801

Probert PK (1975) The bottom fauna of china clay waste deposits in Mevagissey Bay. J Mar Biol Assoc UK 55:19-44

Roughgarden J, Gaines S, Possingham H (1988) Recruitment dynamics in complex life cycles. Science 241:1460-1466
Rumrill SS (1990) Natural mortality of marine invertebrate larvae. Ophelia 32:163-198

Salomon JC (1990) Role of instantaneous and long-term water movements on the recruitment and life of benthic fauna in the English Channel. La Mer 28:211-217

Salomon JC (1991) Hydrodynamic action on benthic macrofauna in tidal coastal zones. ICES Mar Sci Symp 192:15-23

Salomon JC, Breton M (1991) Courants résiduels de marée dans la Manche [special issue]. Oceanol Acta 11:47-53

Salomon JC, Breton M (1993) An atlas of long-term currents in the Channel. Oceanol Acta 16:439-448

Salomon JC, Guéguéniat P, Orbi A, Baron Y (1988) A Lagrangian model for long-term tidally-induced transport and mixing. Verification by artificial radionuclide concentrations. In: Guary JC, Guéguéniat P, Pentreath RJ (eds) Radionuclides: a tool for oceanography. Elsevier, Amsterdam, pp 384-394

Salomon JC, Garreau P, Breton M (1996) The Lagrangian barycentric method to compute 2D and 3D long term dispersion in tidal environments. In: Pattiaratchi C (ed) Mixing in estuaries and coastal seas. (Coastal and estuarine studies, 50) American Geophysical Union, Washington, D.C. pp 59-76

Thiébaut E, Dauvin JC (1991) Etude de la fécondité d'Owenia fusiformis Delle Chiaje (Annélide Polychète). J Rech Océanogr 16:39-41

Thiébaut E, Dauvin JC, Lagadeuc Y (1992) Transport of Owenia fusiformis larvae (Annelida Polychaeta) in the Bay of Seine. I. Vertical distribution in relation to water column stratification and ontogenic vertical migration. Mar Ecol Prog Ser 80:29-39

Thiébaut E, Dauvin JC, Lagadeuc Y (1994) Horizontal distribution and retention of Owenia fusiformis larvae (Annelida:Polychaeta) in the Bay of Seine. J Mar Biol Assoc UK 74:129-142

Thiébaut E, Cabioch L, Dauvin JC, Retière C, Gentil F (1997) Spatio-temporal persistence of the Abra alba-Pectinaria koreni muddy-fine sand community of the Eastern Bay of Seine. J Mar Biol Assoc UK 77:1165-1185

Tremblay MJ, Loder JW, Werner FE, Naimie CE, Page FH, Sinclair MM (1994) Drift of sea scallop larvae Placopecten magellanicus on Georges Bank: a model study of the roles of mean advection, larval behaviour and larval origin. Deep Sea Res II 41:7-49

Underwood AJ, Fairweather PG (1989) Supply-side ecology and benthic marine assemblages. Trends Ecol Evol 4:16-20

Wilson DP (1932) On the mitraria larvae of Owenia fusiformis Delle Chiaje. Philos Trans R Soc Lond Ser B Biol Sci 221:231-334

Young EF, Bigg GR, Grant A, Walker P, Brown J (1998) A modelling study of environmental influences on bivalve settlement in the Wash, England. Mar Ecol Prog Ser 172:197-214 